\title{
Application Rate Trials with a Nuclear Polyhedrosis Virus to Control Spodoptera frugiperda (Smith) on Maize
}

Ivan Cruz ${ }^{1}$, Maria L. C. Figueiredo ${ }^{1}$, Fernando H. Valicente ${ }^{1}$ and

Antônio C. Oliveira ${ }^{1}$

${ }^{1}$ EMBRAPA/CNPMS, Caixa postal 151, 35701-970, Sete Lagoas, MG.

An. Soc. Entomol. Brasil 26(1): 145-152 (1997)

Efeito de Diferentes Doses de Virus de Poliedrose Nuclear para o Controle de Spodoptera frugiperda (Smith) em Milho

RESUMO - Diferentes concentrações de vírus da poliedrose nuclear (VPN) foram aplicadas em suspensão aquosa, usando-se pulverizador (acoplado a um trator ou costal-manual), para o controle de larvas de Spodoptera frugiperda (Smith), em milho (Zea mays L.). A mortalidade das larvas variou com o equipamento de aplicação. Na aplicação via trator, foi necessária uma dose de pelo menos $2,5 \times 10^{12}$ corpos de inclusões poliédricas (CIP)/ha para se ter eficiência comparável a que se obteve com o pulverizador costal-manual $(70,2 \%)$. Para este tipo de pulverizador pode-se usar 2,5 x $10^{11} \mathrm{CIP} / \mathrm{ha}$, porém o efeito residual foi muito curto. Maior persistência foi obtida com doses acima de $1,25 \times 10^{12} \mathrm{CIP} /$ ha (93,4\% de mortalidade). A ocorrência de parasitóides na área experimental propiciou um aumento médio na taxa de mortalidade larval $(16,4 \%)$, independente da metodologia de aplicação. Entre os parasitóides, a maior ocorrência foi de Campoletis flavicincta (Ashmead) (53,0\%), seguido por Chelonus insularis (Cresson) (31,3\%), e Eiphosoma spp. (15,6\%).

PALAVRAS-CHAVE Insecta, lagarta-do-cartucho, Baculovirus, controle biológico.

ABSTRACT - Different concentrations of nuclear polyhedrosis virus were applied as aqueous suspensions using a tractor mounted or a backpack-manual sprayer to control Spodoptera frugiperda (Smith) larvae on maize (Zea mays L.). Larval mortality varied with the application equipment. For the tractor-mounted sprayer application of at least $2.5 \times 10^{12}$ P.I.B./ha was necessary to attain a control comparable to that obtained with the backpack-manual sprayer application (70.2\%). For this application method it can be used the dose of $2.5 \times 10^{11}$ PI.B./ ha, butNPV persistence was very short. A greaterNPV persistence was obtained with doses over $1.25 \times 10^{12}$ P.I.B./ha ( $93.4 \%$ mortality). The occurrence of parasitoids in the experimental area increased larval mortality rate $(16.4 \%)$, independent of the application method. Among the parasitoids, the most prevalent was Campoletis flavicincta (Ashmead) (53.0\%), followed by Chelonus insularis (Cresson) (31.3\%), and Eiphosoma spp. (15.6\%).

KEY WORDS: Insecta, fall armyworm, Baculovirus, biological control.

In Brazil, Spodoptera frugiperda (Smith) is one of the key pests of maize (Zea mays L.) and other row and vegetable crops (Cruz 1980). First-instar larvae usually eat the green tissue 
from one side of the leaf, leaving the membranous epidermis on the other side intact. Older instars make holes in the leaf, and may completely destroy small plants and strip larger ones (Cruz 1995b). Carvalho (1970) reported yield reductions from 15 to $34 \%$, depending on plant age and pest damage level. Cruz \& Turpin (1983) reported a complex relationship between larval infestation and yield, with the relationship of leaf damage and ear weight for dent maize being inversely linear, because of a reduced number of kernels on ears from infested maize plants.

Control of S. frugiperda in maize is based on chemical insecticides, employed when the defoliation is noticed in the crop. However, because of the problems associated with the use of pesticides to control this pest, specially the possibility of insecticide resistance and the reduction of beneficial insects, emphasis has been shifted to biological control (Cruz 1995a,b). Among biological control agents, a S. frugiperda nuclear polyhedrosis virus (SFNPV) is believed to have great potential to control this pest (Gardner et al. 1984, Moscardi \& Kastelic 1985, Valicente \& Cruz 1991).

A microbial insecticide (SFNPV) against S. frugiperda was developed at EMBRAPA/ CNPMS (Valicente et al. 1989). Laboratory trials with an aqueous suspension of purified virus resulted in $100 \%$ mortality, when 3- and 6-day old larvae fed on maize leaves were sprayed with a suspension of $2 \times 10^{6}$ polyhedral inclusion bodies (P.I.B.)/ml (Valicente $e t$ al. 1989). Following these trials, a pilot-scale virus-production plant was established at EMBRAPA/CNPMS and a SFNPV wettable powder formulation was developed (Valicente \& Cruz 1991). This paper describes the field testing of this formulation, applied to maize plants using a backpack-manual sprayer and a tractor-mounted sprayer.

\section{Material and Methods}

The experiments were conducted at EMBRAPA/CNPMS Research Station, Sete Lagoas, MG, on hybrid maize BR 201. Plant height ranged $35-45 \mathrm{~cm}$ at application. A basic wettable powder virus formulation was produced and used in all trials, being applied as an aqueous suspension using sprayers (tractor mounted and backpack-manual) at 40 PSI $\left(2.8 \mathrm{~kg} / \mathrm{cm}^{2}\right)$ and a regular flat fan nozzle (Cruz \& Santos 1984). Spraying was carried out in the morning, between 08:00 and 10:00h.

Tractor-Mounted Sprayer Application. The virus was applied at four concentrations (2.5 x $10^{11}, 1.25 \times 10^{12}, 2.5 \times 10^{12}$ and $5.0 \times 10^{12}$ RI.B./ ha), which were compared to the standard backpack-manual sprayer application $(2.5 \mathrm{x}$ $10^{11}$ P.I.B./ha) and an untreated control. The trial design was a randomized block with six replications, and each plot consisted of six rows $\mathrm{x} 20 \mathrm{~m}$. The four virus doses were applied at $400 \mathrm{l} / \mathrm{ha}$ (360 1/ha for the backpack-manual application). A plastic sheet was used to avoid spray drift between plots, during application, which was made when the plants presented the pin-hole damage symptom. Evaluations were made at three, six and nine days after treatment, by randomly selecting 30 plants/ plot and counting dead and alive larvae. Alive larvae were taken to the laboratory and placed individually in plastic cups with artificial diet. Insects were maintained at $25 \pm 2{ }^{\circ} \mathrm{C}, 70 \% \mathrm{RH}$ and photophase of $12 \mathrm{~h}$, and observed daily, and mortality recorded.

\section{Backpack-Manual Sprayer Application. In} two trials the virus was applied at five concentrations $\left(2.5 \times 10^{11}, 1.25 \times 10^{12}, 2.5 \times 10^{12}\right.$, $1.25 \times 10^{13}$ and $2.5 \times 10^{13}$ P.I.B./ha), and compared to an untreated control. The trial design was a randomized block, with six replications, and each plot consisted of four rows by $5 \mathrm{~m}$ of maize BR 201. Application was performed at $320 \mathrm{l} / \mathrm{ha}$. In the first trial, the virus was applied when the plants presented the pinhole damage symptom. Evaluations were made at five days after spraying, by randomly selecting 15 plants/plot and collecting all larvae, which were transferred to the laboratory for daily observation of mortality, according to the methodology of the previous experiment. 
In the second trial, to isolate the effect of parasitoids and predators, when the plants were $40 \mathrm{~cm}$ tall, an artificial infestation was made with five 8-d old larvae/plant in 15 plants/ plot. The infested plants were protected with a cage made of iron and nylon screening. Forty-eight hours after infestation, cages were removed and plots sprayed with the SFNPV. After application, the previously caged plants were again protected. In the following three days, artificial infestation was made in other 15 non-covered plants/plot, to asses the residual effect of the virus. Efficacy evaluations were made as previously described.

Data on larval mortality were submitted to the analysis of variance and compared using Duncan's multiple range test $(\mathrm{P} \leq 0.05)$. Combined analysis considering the three different samplings as replications through time, was also run for the tractor-mounted sprayer application test.

\section{Results and Discussion}

Tractor-Mounted Sprayer Application. At three days after application, the mean mortality caused by the SFNPV varied from 30.5 to $65.4 \%$ in plots where the virus was applied by the tractor-mounted sprayer, compared to $74.0 \%$ in plots treated using the backpackmanual sprayer (Table 1), This mortality was significantly different from all treatments at the period of 3-d after application. The mortality in plots treated by the tractor-mounted sprayer increased with the increase of the NPV dose. However, even at the higher dose larval mortality $(65.4 \%)$ was significantly lower than that observed in plots treated with the backpack-manual sprayer $(74.0 \%)$. At 6$\mathrm{d}$ after spraying a significant higher mortality $(79.4 \%)$ was observed in plots treated by the tractor-mounted sprayer at $5.0 \times 10^{11}$ P.I.B./ha. There was no difference between the mortality observed in plots treated by the backpackmanual sprayer $(66.8 \%)$ and those treated by the tractor-mounted sprayer at the dose of 2.5 x $10^{11}$ P.I.B./ha (62.3\%). At 9-d after application there were no significant differences in the mortality observed between plots treated with the tractor-mounted sprayer at doses higher than $1.25 \times 10^{11}$ P.I.B./ha and plots treated with the backpack-manual sprayer (Table 1). The mortality by the NPV in untreated plots increased through time, probably due to natural occurrence of the virus and migration of infected larvae from NPV treated plots to untreated plots.

The analysis considering the different sampling intervals as replications through time indicated no effect of sampling time neither interaction between factors. Mean mortality for the untreated control $(9.8 \%)$ was significantly lower than that of all other treatments. Highest mean mortalities were obtained in plots treated with the backpack-manual sprayer $(70.2 \%)$ and in those treated by the tractormounted sprayer $(60.6$ and $68.3 \%)$ at the two highest NPV doses. Regression analysis on mean NPV mortality showed a linear relationship between doses and mortality $(\mathrm{Y}=34.52$ $+1.86 \mathrm{X}, \mathrm{R}=0.95, \mathrm{P} \leq 0.05$ ).

The application of SFVPN apparently had some effect on parasitoid incidence [(the most prevalent was Campoletis flavicincta (Ashmead) (53\%), followed by Chelonus insularis (Cresson) (31.3\%), and Eiphosoma spp. (15.6\%)], as mortality of S. frugiperda larvae caused by parasitoids was lower in plots treated with the highest SFNPV dose (Table 1). This situation could be explained by a faster mortality caused by the higher doses of NPV However, it can be observed that, although the mortality by the virus was the same in the two highest doses applied by the tractormounted sprayer, there was a significant difference between the two treatments in relation to mortality caused by parasitoids. When the mean mortality of the three sampling periods was considered, the treatment with $5.0 \times 10^{12}$ P.I.B./ha resulted in significantly lower (8.8\%) parasitoid incidence on $S$. frugiperda larvae, compared to values ranging from 15.5 to $21.5 \%$ in other NPV treatments.

Considering SPVPN and parasitoids altogether, mortality varied from 50.3 to $92.7 \%$ from insects collected at $3-\mathrm{d}$ application, from 
$50.4 \%$ to $87.3 \%$ at 6-d and from 61.1 to $83.7 \%$ from those collected at the 9th day (Table 1). $S$. frugiperda mortality on untreated plots was significantly lower than in NPV treated plots. Highest control of larvae was obtained in plots treated with the backpack-manual sprayer at $2.5 \times 10^{11}$ P.I.B./ha or with the tractormounted at $2.5 \times 10^{12}$ P.I.B./ha, showing the former method to be more effective than the tractor mounted application. Lower control efficiency provided by this application method may be attributed to a greater loss of NPV applied away from the whorl of maize plants, by the desuniformity of planting and/or ability of the operator.

The presence of natural enemies such as predators (especially Doru luteipes Scudder) and parasitoids can act in independent fashion and promote an increase in the total mortality of $S$. frugiperda larvae. In general, it was observed a positive relationship between parasitoids and SPNPV However, this relationship should be further investigated, particularly because the consistently lower number of parasitoids found in plots treated with the highest virus dose.

Backpack-Manual Sprayer Application. In the first trial, the virus was applied on plants showing the pin-hole damage, indicating at- tack by small larvae. Mean mortality in the untreated plots was high $(33.0 \%)$, probably due to larval migration to other plots or to natural virus occurrence. However, mean mortality by the virus in the check was significantly lower than in the virus-treated plots. The mean mortality obtained by application of the standard dose of $2.5 \times 10^{11}$ P.I.B./ha was $71 \%$. At the four higher doses mean mortality rates were $77.6,82.4,85.0$ and $84.0 \%$, respectively, which were not significantly different (Table 2 ). Compared to the same doses applied with the tractor-mounted sprayer (mean mortality of 45.6 $\%)$, the backpack-manual sprayer application resulted in a mean mortality $32.1 \%$ higher (mortality of $77.7 \%$ ), showing signiffcant differences between the application methods.

The occurrence of parasitoids was significantly higher in the untreated plots (mortality of $21.1 \%$ ) than in virus-treated plots (mean of $6.9 \%$ ), with a tendency of lower parasitoid incidence with the increase in virus doses (Table 2). Total mortality of S. frugiperda larvae was $54.1 \%$ in untreated plots, and varied from 78.4 to $90.8 \%$ in virus-treated plots. There was no increase in mortality for doses greater than $1.25 \times 10^{12}$ P.I.B./ha. It becomes evident from this test that, even with the backpackmanual sprayer, the dose of SFNPV should be at least $1,25 \times 10^{12}$ P.I.B./ha.

Table 2. Percentage larval mortality of Spodoptera frugiperda caused by different concentrations of SFNPV applied by backpack sprayer and naturally-occurring parasitoids.

\begin{tabular}{lccc}
\hline $\begin{array}{c}\text { Doses of } \\
\text { Baculovirus } \\
\text { (P.I.B. / ha) }\end{array}$ & NPV & Parasitoids & Total \\
\cline { 2 - 4 } $2.50 \times 10^{11}$ & $71.0 \pm 5.2 \mathrm{~b}$ & $7.4 \pm 1.9 \mathrm{bc}$ & $78.4 \pm 4.3 \mathrm{~b}$ \\
$1.25 \times 10^{12}$ & $77.6 \pm 1.4 \mathrm{ab}$ & $10.5 \pm 1.7 \mathrm{~b}$ & $88.1 \pm 2.0 \mathrm{a}$ \\
$2.50 \times 10^{12}$ & $82.4 \pm 3.0 \mathrm{a}$ & $6.4 \pm 1.8 \mathrm{bc}$ & $88.7 \pm 3.2 \mathrm{a}$ \\
$1.25 \times 10^{13}$ & $85.0 \pm 1.2 \mathrm{a}$ & $3.4 \pm 1.3 \mathrm{c}$ & $88.4 \pm 1.8 \mathrm{a}$ \\
$2.50 \times 10^{13}$ & $84.0 \pm 3.7 \mathrm{a}$ & $6.7 \pm 2.4 \mathrm{bc}$ & $90.8 \pm 2.1 \mathrm{a}$ \\
Untreated & $33.0 \pm 2.5 \mathrm{c}$ & $21.1 \pm 4.0 \mathrm{a}$ & $54.1 \pm 4.6 \mathrm{c}$ \\
\hline CV $\%)$ & 9.4 & 34.7 & 8.4 \\
\hline
\end{tabular}

${ }^{1}$ Means within each column followed by the same letter are not significantly different $(\mathrm{P} \leq 0.05$; Duncan's multiple range test). 
The natural $S$. frugiperda infestation was high, with a mean of three larvae per plant. Mortality was $72.2 \%$ due to SFNPV and $9.2 \%$ due to parasitoids. The natural occurring enemies are very important because they lay eggs in the eggs or in small S. frugiperda larvae, eliminating them before they cause substantial damage to maize plants (Rezende et al. 1994, Cruz et al. 1995).

In the second trial, involving cage-protected plants, there was no death caused by parasitoids on $S$. frugiperda larvae. Using caged plants, added to the occurrence of cloudy sky at and thereafter application, might have prolonged virus activity, due to lower intensity of UV radiation during the test. In general, mean mortality after the application of SFNPV on the larvae was high. It varied from 90.5 (standard dose of $2.5 \times 10^{11}$ P.I.B./ ha) to over $97.3 \%$ (doses higher than $1.25 \mathrm{x}$ $10^{12}$ P.I.B./ha) (Table 3).

The residual effect of the virus was observed by artificial infestation with 8-day old larvae just after SFNPV application and at 1, 2 and 3-d after treatment (Table 3). In general the same differences occurred among the treatments. At the 1-d residual effect, the mortality rate varied from $71.5 \%$ (standard dose) to an average of $96.1 \%$ for the other NPV doses. At the 3-d residual effect, mean mortality dropped to $57.8 \%$ in the plots treated with the standard dose. The mean mortality rate was basically the same for al other treatments. Within each dose, there were significant differences on mortality only for the standard dose $(2.5 \times 10$ ${ }^{11}$ P.I.B./ha) which had a tendency to present decreasing of mortality over time (Table 3 ). For all other virus treatments the mortality was the same for the three days of evaluations. According to Moscardi (1986), the entomopathogens in general are very sensitive to the UV radiation and can be broken down within the first $48 \mathrm{~h}$ after application. Working with three different formulations, purified, unpurified and purified virus plus adjuvant of Baculovirus anticarsia applied on soybean leaves the author reported a decrease on the activity of the virus to 25.60 and $80 \%$, respectively, at 6-d after application. In our experiment the data were taken only in a 3-d period. A greater period should be considered to best discriminate among the doses. However, the experiment was sufficient to show that the standard dose of $2.5 \times 10^{11}$ P.I.B./ha is not sufficient to be used to control the pest, because

Table 3. Percentage larval mortality of Spodoptera frugiperda caused by different concentrations of SFNPV applied by a backpack-manual sprayer, and persistence of the virus on maize plants.

\begin{tabular}{lcccc}
\hline $\begin{array}{l}\text { Doses of } \\
\text { Baculovirus } \\
\text { (P.I.B. / ha) }\end{array}$ & Curative & $\begin{array}{c}\text { 1-day } \\
\text { residual }\end{array}$ & $\begin{array}{c}\text { 2-day } \\
\text { residual }\end{array}$ & $\begin{array}{c}\text { 3-day } \\
\text { residual }\end{array}$ \\
\cline { 2 - 5 } & & & & \\
$2.50 \times 10^{11}$ & $90.5 \pm 2.0 \mathrm{~B} \mathrm{a}$ & $71.5 \pm 6.3 \mathrm{~B} \mathrm{ab}$ & $74.5 \pm 5.4 \mathrm{AB} \mathrm{ab}$ & $57.8 \pm 12.6 \mathrm{~B} \mathrm{~b}$ \\
$1.25 \times 10^{12}$ & $97.3 \pm 2.0 \mathrm{~A} \mathrm{a}$ & $92.9 \pm 4.0 \mathrm{~A} \mathrm{a}$ & $96.3 \pm 3.7 \mathrm{~A} \mathrm{a}$ & $87.3 \pm 8.1 \mathrm{~A} \mathrm{a}$ \\
$2.50 \times 10^{12}$ & $99.2 \pm 0.8 \mathrm{~A} \mathrm{a}$ & $93.4 \pm 2.6 \mathrm{~A} \mathrm{a}$ & $80.4 \pm 6.2 \mathrm{~A} \mathrm{a}$ & $93.1 \pm 3.4 \mathrm{~A} \mathrm{a}$ \\
$1.25 \times 10^{13}$ & $97.8 \pm 1.4 \mathrm{~A} \mathrm{a}$ & $100.0 \pm 0.0 \mathrm{~A} \mathrm{a}$ & $95.9 \pm 2.6 \mathrm{~A} \mathrm{a}$ & $100.0 \pm 0.0 \mathrm{~A}$ a \\
$2.50 \times 10^{13}$ & $98.6 \pm 1.3 \mathrm{~A} \mathrm{a}$ & $98.1 \pm 1.8 \mathrm{~A} \mathrm{a}$ & $100.0 \pm 0.0 \mathrm{~A} \mathrm{a}$ & $100.0 \pm 0.0 \mathrm{~A} \mathrm{a}$ \\
Untreated & $15.6 \pm 3.9 \mathrm{C} \mathrm{b}$ & $42.0 \pm 10.3 \mathrm{C} \mathrm{a}$ & $50.1 \pm 8.3 \mathrm{~B} \mathrm{a}$ & $52.5 \pm 16.0 \mathrm{~B} \mathrm{a}$ \\
\hline $\mathrm{CV}(\%)$ & 6.2 & 15.3 & 30.1 & 27.0 \\
\hline
\end{tabular}

${ }^{1}$ Means followed by the same capital letter within each column or small letter across each line are not significantly different $(\mathrm{P} \leq 0.05$; Duncan's multiple range test). 
the significantly lower mortality and the short persistence in the field.

In general, considering all the trials shown here, it can be concluded that the SFNPV can be used to control the $S$. frugiperda larvae. However, the dose will depend on the application equipment. When applied with a backpack-manual sprayer it can be used at $2.5 \mathrm{x}$ $10^{11}$ P.I.B./ha. However, virus persistence is very short at this dose. Longer persistence is obtained at doses higher than $1.25 \times 10^{12}$ RI.B./ ha. For the tractor-mounted sprayer application, a dose of at least $2.5 \times 10^{12}$ P.1.B./ha will be necessary to get a control compared to that obtained with the backpack sprayer application. In areas of high occurrence of natural enemies an increase of efficacy by the application of the virus could be expected, independent on the application method. The use of SFNPV could contribute in fact to increase the prevalence of these and other natural enemies in maize fields (Valicente \& Costa 1995).

\section{Acknowledgments}

We thank FAPEMIG (Minas Gerais State Research Foundation) for financial support to this research.

\section{Literature Cited}

Carvalho, R.P.L. 1970. Danos, flutuação da população, controle e comportamento de Spodoptera frugiperda (J.E. Smith, 1797) e susceptibilidade de diferentes genótipos de milho, em condições de campo. Tese de doutorado, ESALQ/USP, Piracicaba, SP, 170p.

Cruz, I. 1980. Impact of fall armyworm, Spodoptora frugiperda (Smith and Abott 1797) on grain yield in field com. M. Sc. thesis, Purdue University, West Lafayette. Indiana, USA, 162p.
Cruz, 1.1995a. Manejo Integrado de Pragas de milho com ênfase para o controle biológico. In: Ciclo de Palestras sobre Controle Biológico de Pragas, 4., Campinas, SP, 170p.

Cruz, 1.1995b. A lagarta-do-cartucho na cultura do milho. Sete Lagoas, EMBRAPA, CNPMS,Circ.Téc.21,45p.

Cruz, I., D .A. N. Lima, M. L. C. Figueiredo \& F. H. Valicente. 1995. Aspectos biológicos do parasitóide Campoletis flavicincta (Ashmead) criados em lagartas de Spodoptera frugiperda. An. Soc. Entomol. Brasil 24:201-208.

Cruz, I. \& J. P. Santos. 1984. Diferentes bicos do tipo leque no controle da lagartado-cartucho em milho. Pesq. Agropec. Brás. 19: 1-7.

Cruz, I. \& F.T.Turpin. 1983. Yield impact of larval infestation of the fall armyworm Spodoptera frugiperda (J. E. Smith) to mid-whorl growth stage of com. J. Econ. Entomol.76:1052-1054.

Gardner.W.A., R. Noblet \& R. D. Schwehr. 1984. The potential of microbial agents in managing populations of the fall armyworm. Florida Entomol. 67:325-332.

Moscardi, F. 1986. Utilização de vírus para controle da lagarta-da-soja. p. 188-202. In S. B. Alves. Cood. Controle microbiano de insetos. Manole. São Paulo. 407p.

Moscardi, F. \& J. G. Kastelic. 1985. Ocorrência de vírus de poliedrose nuclear e vírus de granulose em populações de Spodotera frugiperda atacando soja na região de Sertaneja, PR. Res. Pesq., Documentos 15, Londrina, 49p. 
Rezende, M. A. A, I. Cruz \& T. M. C. Delia Lúcia. 1994. Consumo foliar de milho e desenvolvimento de lagartas de Spodoptera frugiperda (Smith) parasitadas por Chelonus insularis (Cresson) (Hymenoptera: Braconidae). An. Soc. Entomol. Brasil 23:473-478.

Valicente, F. H. \& E. F. Costa. 1995. Controle da lagarta do cartucho, Spodoptera frugiperda (J.E. Smith), com o Baculovirus Spodoptera, aplicado via água de irrigação. An. Soc. Entomol. Brasil 24:61-67.
Valicente, F. H. \& I. Cruz. 1991. Controle biológico da lagarta-do-cartucho, Spodoptera frugiperda, com o baculovirus. Sete Lagoas, EMBRAPA, CNPMS. Circ. Tec.15.23p.

Valicente, F. H., M. J. V. V. D. Peixoto, E. Paiva \& E. Kitajima. 1989. Identificação e purificação de um virus de poliedrose nuclear da lagarta do cartucho, Spodoptera frugiperda. An. Soc. Entomol. Brasil. 18:71-82.

Received 9/11/96. Accepted 17/11/97. 